\title{
contenpooraneity
}

\section{Yesterday's Contemporaneity Finding Temporality in the Past}

Jacqueline M. Lombard

\begin{abstract}
About the Editor-in-Chief
Jacqueline Lombard is a Ph.D. Candidate at the University of Pittsburgh. She specializes in medieval art history, with a particular focus on the history of art objects as products or conduits of cross-cultural exchange between Medieval Europe, the Middle East, and Africa. Her dissertation examines images of Africans that were circulating in Europe during the tenth through twelfth centuries to explore how medieval European artists used visual languages to communicate ideas about identity, globality, and race. She is currently based in Frankfurt am Main as a guest researcher at the Goethe University through the support of a DAAD research grant.
\end{abstract}




\section{Yesterday's Contemporaneity}

\author{
Finding Temporality in the Past
}

Contemporaneity refers to the state of existing in time, within a particular moment, as agents alongside agents. Crucial to the idea of contemporaneity is the recognition that there is a multiplicity of ways to exist within any given moment in time. The act of defining contemporaneity to make sense of the past is a foundational practice in the field of art history, even when it is not the explicit goal of the art historian. To attempt to study a work of art within its own time is to stake a claim about what that time entailed, and what and who the people of that moment understood to be coeval with themselves. Even to nominate the relevance of one historical entity to another is to declare them to be contemporaneous.

While the concept of contemporaneity is often invoked in studies of the present, it is less frequently linked to historical inquiry. Yet it remains true that everything now historical was at some point contemporary, and thus this line of inquiry remains ever-relevant as a means of exploring the ways in which people of the past have defined themselves and their own positions in history. In order to investigate the varied histories of time, and the distinct role that art objects can play in defining or altering perceived temporalities, this edition assembles articles, symposium papers, conversations, and book and exhibition reviews to examine the implications of temporality and contemporaneity across a breadth of historical contexts.

This topic, as the contributions in this edition attest, is as much a historical issue as it is a historiographical one. While grappling with historic conceptions of time, it is just as critical to decipher the preconceived, or sometimes anachronistic, notions of time and periodization that have been imposed on any given moment or culture. The contributions in this edition highlight the efforts of art historians and artists now and in the past to navigate the multiple layers of narrative that have molded any given moment in time.

In "The Sands of Time: Medhi-Georges Lahlou's Aesthetics of Disorientation," Conor Moynihan situates Medhi-Georges Lahlou's work alongside the history of Orientalist thought from the eighteenth-century to today. He maintains that Orientalism has acted as a disabling force on historical and contemporary Middle Eastern and North African cultures by freezing them in a fictional past. In turn, Moynihan explores Medhi-Georges' arts practice as a means of re-asserting the artist's own contemporaneity by disorienting Orientalist expectations. In another conversation around the legacies of Western colonial perspectives, Monika Siebert and Marina Tyquiengco examine the role of Native American imagery in the United States. Their discussion focuses on Siebert's recent book Indians Playing Indian and a recent exhibition from the Smithsonian National Museum of the American Indian (NMAI), titled Americans, which opened on January 18, 2018, and will continue through 2022. Siebert and Tyquiengco unpack the multiple ways in which the proliferation of Native American imagery in mainstream American culture informs widespread beliefs about Indigenous peoples while simultaneously acting to define American cultural identity as a whole. Siebert and Tyquiengco also examine the instution of the NMAI, where they conducted their conversation, as a conduit for exploring these narratives.

This edition also features two conversations between art historians and artists whose work grapples with external impositions of cultural and temporal perceptions by appropriating historical imagery and issues for a present-day dialogue. In "The Canaries of Democracy: Imagining the Wandering Jew with Artist Rosabel Rosalind Kurth-Sofer," Rae Di Cicco speaks with Rosabel Rosalind Kurth-Sofer about the relationships between Kurth-Sofer's faith and artistic practice and the long history of anti-Semitism. Thomas Messersmith introduces the conversation with an essay on the broader history of anti-Semitic imagery and thought, as Kurth-Sofer describes how she, as a Jewish woman, has navigated and appropriated archives full of anti-Semitic imagery towards a new purpose. The approach that Kurth-Sofer takes 
towards this particularly painful and persistent past resonates with another conversation in this edition: "From Axayácatl to El Chapo: Rethinking Migration and Mexico's War on Drugs in Gabriel Garcilazo's Dystopic Magical Codex." Here, Adriana Miramontes Olivas speaks with artist Gabriel Garcilazo, whose work Dystopic Magical Codex (2015) confronts the social and political consequences of the Mexican war on drugs as a piece of Mexico's longer history. Positioning Garcilazo's work against both contemporary politics and historical manuscripts, such as the sixteenth-century Codex Azcatitlan, Miramontes Olivas and Garcilazo explore ability of art to re-engage and re-contextualize historical memory.

In her exhibition review, Carolyn Wargula writes on Fujiwo Ishimoto, an artist who also works within a cross-temporal dialogue, as well as a cross-cultural one. Wargula examines Fujiwo Ishimoto Exhibition: From Marimekko Flowers to Ceramic Fruits in Dialogue with the Rinpa, as it was on view from March 9 to April 21, 2019, at the Hosomi Museum in Kyoto, Japan. Wargula commends the dialogues the show facilitated across cultures, as Ishimoto is a Japanese designer working for a Finnish firm, as well as across time, as his art regularly employed the historic Rinpa style, which was popularized in Japan during the Edo period (c.1603-1868).

The issue also includes a special section dedicated to Motivating Monuments, the 2018 iteration of the University of Pittsburgh's History of Art and Architecture Department's biannual symposium. The symposium brought together speakers addressing a wide range of monuments and the political power they hold as public articulations of identity, community, and memory. Monuments can serve as testaments to a bygone event or societal value, or as grandiose attempts to preserve some form of public memory. Thus, conceptually, monuments hinge on time and the fundamental relationship between present and past. In her paper, "So shall yoe bee: Encountering the Shrouded Effigies of Thomas Beresford and Agnes Hassall at Fenny Bentley," Aimee Caya addresses the elusive Beresford Monument, a funerary monument that depicts its subjects in their funeral shrouds, thereby concealing all markers of their individuality. By contextualizing the monument alongside other late medieval artistic and devotional practices, Caya argues that this iconographic strategy was designed to evoke particular empathetic responses in viewers. While Caya explores the power of anonymization in her contribution, another speaker from the symposium, Ramey Mize, discusses the power of likeness and physical contact by addressing a set of plaster casts taken of Abraham Lincoln's hands and face by Leonard Wells Volk in 1860. Drawing on theories of medieval sanctification and relic function, Mize examines the legacies of the casts to argue that the casts functioned as a type of modern relic that supported the ongoing sanctification of this American president.

Our book review section features three reviews of recent publications on Renaissance art, a field that has long grappled with temporality and periodization as critical historiographic issues. Andrea Kibler Maxwell reviews Saints, Miracles and the Image: Healing Saints and Miraculous Images in the Renaissance (2019). Edited by Sandra Cardarelli and Laura Fenelli, this volume presents a range of case studies from Renaissance Italy in order to further flesh out the complicated and dynamic history of images as both cult objects and objects of art, thereby challenging the previously established belief that 1500 marked a fundamental shift between these two modes of image function. Christopher J. Nygren evaluates Raphael and the Redefinition of Art in Renaissance Italy (2017) by the late Robert Williams (d. 2018). Nygren describes the book as a novel perspective on the modernity of Raphael, as Williams highlights essential yet underrecognized aspects the artist's modernity including his labor practices and approaches to style and decorum. Finally, Sarah Reiff Conell assesses Art and Miracle in Renaissance Tuscany (2018) by Robert Maniura, a monograph that highlights the life of Giuliano di Francesco Guizzelmi (1446-1518) and his role in shaping the Marian cults of his time in Prato. Conell commends the book for its depth and insight into its focused case study, and further considers the potential of such a methodological approach alongside contemporary discussions of network theory.

Contemporaneity has always been underpinned by the continued support and effort of countless individuals at the University of Pittsburgh. It is with the utmost sincerity that I thank 
all of the people who have made Edition 8 possible, including Jacob Eisensmith, Emi Finkelstein, Paulina Pardo Gaviria, Rebecca Giordano, Paula Kupfer, Katie Loney, Krystle Stricklin, and Yijing Wang, who served together as this edition's formidable editorial board, as well as David Tenorio who acted as a guest editor for this edition. These thanks must also be extended to our many peer reviewers who volunteered their time to support and improve the scholarship featured in this edition. I also thank Jennifer Josten, Kate Joranson, Barbara McCloskey, Terry Smith, and Alex Taylor. Their constant support and insight as our advisory board helped guide this edition to completion. Former editors Marina Tyquiengco, Rae Di Cicco, Nicole Scalissi as well as all the past editors-in-chief deserve the highest praise for the work they have put in to making this journal what it is today, and for their constant generosity and mentorship. I also thank Annalisa Zox-Weaver, whose sharp eyes and editorial acumen have bettered this journal every year that she has acted as our copyeditor, this year included. Vanessa Gabler, Kari Johnston, and the entire team that make up the University Library System at Pitt also have our endless gratitude for all of the work that they do to make our journal possible. This year in particular has also been a monumental one for Contemporaneity as we have launched our new website, complete with a new design and new publishing template. We could never have executed this effort without their constant support, knowledge, and enthusiasm.

Contemporaneity thrives on the voluntary labor of these people and many more, all of whom are driven by love for this journal and by a true commitment to publishing quality openaccess scholarship. It is because of their constant support that we may proudly present our eighth edition, which we hope will serve to inspire and inform many conversations to come.

(c) $\mathbf{E Y}$ 4.0 United States License.

\section{UILIS D-Sork}

This journal is operated by the University Library System of the University of Pittsburgh as part of its D-Scribe Digital Publishing Program, and is co-sponsored by the University of Pittsburgh Press. 